Dawid Niemczycki

Szkoła Doktorska Nauk Społecznych UMCS

\title{
Interes prawny a proces kościelny. Glosa aprobująca do wyroku Naczelnego Sądu Administracyjnego z 8 maja 2015 r., II OSK 2416/13
}

Treść: Wstęp. 1. Teza rozstrzygnięcia. 2. Przesłanki stanu faktycznego i prawnego. 3. Argumentacja Naczelnego Sądu Administracyjnego. 4. Ocena wyroku. Zakończenie.

\section{Wstęp}

Normy prawa kanonicznego stanowią, iż kto chce kogoś pozwać, musi przedłożyć właściwemu sędziemu skargę powodową, w której przedstawi przedmiot sporu i wyrazi prośbę o posługę sędziego (por. kan. 1502 KPK i art. $115 \$ 1$ DC). Skarga powodowa zaś powinna wskazywać stałe lub tymczasowe zamieszkanie strony pozwanej (por. kan. 1504 n. 4 KPK oraz art. $116 \$ 1$ n. 5 DC).

Istotnym jest wskazanie, że KPK oraz DC mówi o „zamieszkaniu”, zaś Ustawa o ewidencji ludności ${ }^{1}$ używa pojęcia „zameldowania”. Nie należy oczywiście utożsamiać tych pojęć i stosować ich zamiennie. W orzecznictwie sądowym podnosi się, iż prawna konstrukcja „miejsca zamieszkania” obejmuje rzeczywiste przebywanie w pewnej

1 Por. Ustawa z 24 września 2010 r. o ewidencji ludności, Dz.U. 2010 Nr 217 poz. 1427. 
miejscowości w sensie fizycznym i wolę, zamiar stałego pobytu ${ }^{2}$. Meldunek jest jedynie spełnieniem administracyjnego obowiązku ewidencji ludności i nie zawsze jest zgodny z określonym de facto miejscem zamieszkania ${ }^{3}$.

Niejednokrotnie zdarza się, iż osoba wnosząca skargę o stwierdzenie nieważności małżeństwa nie dysponuje aktualnym adresem zamieszkania strony pozwanej. Nie jest świadoma jednak faktu, iż brak cytacji, czyli wezwania strony pozwanej rodzi poważne komplikacje procesowe.

Doktryna kanonistyczna postrzega je niejednorodnie. C. Gullo ${ }^{4}$, G. Leszczyński ${ }^{5}$ i J. Gręźlikowski ${ }^{6}$ wskazują, iż brak cytacji pociąga za sobą nieważność usuwalną wyroku. Z kolei M.J. Arroba Conde ${ }^{7}$ i G. Erlebach ${ }^{8}$ stoją na stanowisku, iż niewezwanie pozwanego suponuje istnienie nieważności nieusuwalnej wyroku sądu kościelnego.

Strona powodowa nie znająca konsekwencji takiego stanu rzeczy podaje w skardze ostatnie znane miejsce zamieszkania i dokonuje złożenia prośby we właściwym sądzie kościelnym. Trybunał dokonuje cytacji pozwanego, ustalając, czy ma on odnieść się na piśmie do żądań powoda, czy też stawić się przed trybunałem osobiście. Pozwany $\mathrm{z}$ uwagi na niepoprawnie wskazany adres nie odbiera korespondencji z sądu kościelnego. Sąd kościelny nie posiadający takich informacji wysyła kolejne wezwanie (por. kan. $1676 \$ 2 \mathrm{MIDI}$ ), które również pozostaje bez odpowiedzi. Wówczas zwraca się z prośbą do strony

2 Por. Postanowienie Naczelnego Sądu Administracyjnego z 28 czerwca 2012 r. I OW 82/12, LEX nr 1334606.

3 TAMŻE.

4 Por. C. Gullo, Prassi processuale nette cause canoniche di nullità del matrimonio, Città del Vaticano 2001, s. 93.

5 Por. G. Leszczyński, Gwarancje prawa do obrony w świetle Instrukcji Dignitas connubii, Ius Matrimoniale 13 (19) 2008, s. 113.

6 Por. J. GręźLIKowski, Racje i sens "prawa do obrony” w procesie o nieważność małżéstwa, Prawo Kanoniczne 53 (2010), nr 3-4, s. 210.

7 Por. M.J. Arroba Conde, Diritto processuale canonico, Roma 1993, s. 301.

${ }^{8}$ Por. G. Erlebach, Il giudice e il diritto di difesa delle parti, w: II diritto di difesa nel processo matrimoniale canonico, Città del Vaticano 2006, s. 104-106. 
powodowej o wskazanie aktualnego adresu, pod którym pozwany odbierze korespondencję.

Strona powodowa uruchamiała procedurę administracyjną pozyskania danych jednostkowych w postaci adresu zameldowania na pobyt stały lub adresu zameldowania na pobyt czasowy. Zwracając się ze stosownym wnioskiem, wskazywała swój interes prawny, stwierdzając, że jest stroną postępowania o stwierdzenie nieważności małżeństwa kościelnego.

Każdy z tych wniosków jednak był traktowany podobnie, czyli wskazywano, iż strona zainteresowana nie legitymuje się interesem prawnym ${ }^{9}$, gdyż sądy kościelne nie sprawują wymiaru sprawiedliwości w Rzeczypospolitej Polskiej i nie są organem władzy sądowniczej, a jedynie instytucją społeczności wyznaniowej ${ }^{10}$. Skutkowało to zaistnieniem jedynie interesu faktycznego, ale wiązał się on $\mathrm{z}$ koniecznością pozyskania zgody osoby, której dane usiłowało się pozyskać. Jak można się domyślić, osoba zainteresowana spotykała się z odmową swojego byłego współmałżonka. W związku z tym wydawano decyzję administracyjną odmawiającą udostępnienia wskazanych danych osobowych.

Większość osób rezygnowała na tym etapie sprawy albo składała wniosek o ponowne rozpoznanie sprawy. Decyzja organu administracji publicznej była jednak niezmienna. Niektórzy zaś chcąc pozyskać dane strony pozwanej wnosili skargę na decyzję do właściwego sądu administracyjnego. Jednakże orzeczenia sądowe argumentowano podobnie, wskazując, iż prowadząc postępowanie przed sądem kościelnym nie można wykazać się interesem prawnym w żądaniu uzyskania danych osobowych opartym na konkretnej powszechnie obowiązującej normie prawnej ${ }^{11}$.

\footnotetext{
9 „Wykazanie interesu prawnego w żądaniu uzyskania danych osobowych, ma polegać na wskazaniu okoliczności, które w świetle przepisów prawa materialnego kreują ten interes prawny, a nie na wskazaniu wprost przepisu"; por. Wyrok Naczelnego Sądu Administracyjnego z 9 lutego 2011 r. II OSK 180/10, LEX nr 992500. 10 Por. Wyrok Wojewódzkiego Sądu Administracyjnego w Warszawie z 27 maja 2013 r. IV SA/Wa 2049/12, LEX nr 1609353.
}

11 TAMŻE. 
8 maja 2015 r. nastąpił przełom w postrzeganiu interesu prawnego. Przyjrzyjmy się bliżej temu rozstrzygnięciu.

\section{Teza rozstrzygnięcia}

Naczelny Sąd Administracyjny w Warszawie stwierdził, iż interes prawny warunkujący udostępnienie danych osobowych można mieć nie tylko w procesie przed sądem świeckim, ale również w postępowaniu przed sądem kościelnym ${ }^{12}$. Wyrok ten całkowicie zrewolucjonizował postrzeganie procesu o stwierdzenie nieważności małżeństwa. Od tego momentu strona w postępowaniu przed sądem kościelnym zyskała rangę interesu prawnego ${ }^{13}$.

\section{Przesłanki stanu faktycznego i prawnego}

W grudniu 2011 r. L.K. złożył wniosek do Ministra Spraw Wewnętrznych (obecnie Minister Spraw Wewnętrznych i Administracji) o udostępnienie ze zbioru PESEL danych adresowych w postaci adresu zameldowania na pobyt stały A.K. - strony pozwanej w procesie o stwierdzenie nieważności małżeństwa przed Sądem Metropolitalnym.

Na podstawie decyzji administracyjnej wydanej w czerwcu $2012 \mathrm{r}$. Minister Spraw Wewnętrznych odmówił udostępnienia żądanych danych L.K., gdyż stwierdził, że nie posiada on interesu prawnego, który wymagany był na podstawie - uchylonej już - ustawy z 10 kwietnia 1974 r. o ewidencji ludności i dowodach osobistych.

\footnotetext{
12 Por. Wyrok Naczelnego Sądu Administracyjnego z 8 maja 2015 r. II OSK 2416/13, LEX nr 1678944.

13 Ujęcie „interesu prawnego” zostało szeroko omówione w doktrynie prawniczej. Por. A.S. DudA, Interes prawny w polskim prawie administracyjnym, Warszawa 2008; por. M. JAśkowska, Pojęcie interesu prawnego jako kryterium wyznaczenia pojęcia strony w postępowaniu przed Naczelnym Sądem Administracyjnym, w: Z. NiewiAdomski, Z. Cieślak (red.), Prawo do dobrej administracji: materiały ze Zjazdu Katedr Prawa Postępowania Administracyjnego, Warszawa-Dębe 23-25 września 2002 r., Warszawa 2003 r.
} 
Organ administracji publicznej odwołał się do rozdzielności jurysdykcji sądownictwa świeckiego i kościelnego. Wskazał również, że sąd kościelny jest jedynie instytucją społeczności wyznaniowej, przez co do sakramentalnego związku małżeńskiego odnoszą się jedynie przepisy prawa kanonicznego, które obowiązują wyłącznie w Kościele katolickim.

Minister Spraw Wewnętrznych uznał jedynie, że L.K. posiada interes faktyczny w pozyskaniu danych ze zbioru PESEL i rozpoznał jego wniosek. Takie ujęcie sprawy spowodowało konieczność pozyskania zgody osoby, których dane dotyczą. Organ administracji publicznej zwrócił się do A.K. o wyrażenie zgody na udostępnienie jej danych, jednak do momentu wydania decyzji nie uzyskał stosownej zgody. Ostatecznie zaś potraktowano to jako niespełnienie przesłanki legalności udostępnienia danych, w konsekwencji czego wydano decyzję odmawiającą udostępnienia żądanych danych.

L.K. wniósł o ponowne rozpoznanie sprawy, lecz Minister Spraw Wewnętrznych na mocy decyzji administracyjnej utrzymał w mocy stanowisko wyrażone poprzednio. L.K. złożył skargę na decyzję organu administracji publicznej. W odpowiedzi na skargę Minister podtrzymał argumentację przedstawioną w zaskarżonej decyzji i wniósł o jej oddalenie.

Wojewódzki Sąd Administracyjny w Warszawie wyrokiem z maja 2013 r. ${ }^{14}$ oddalił skargę. Sąd stwierdził, iż Minister w sposób zasadny uznał, że L.K. nie wykazał istnienia interesu prawnego. W uzasadnieniu wyroku WSA powołał się na przepisy Konstytucji RP (art. 10 ust. 2, art. 25 ust. 4 i art. 175 ust. 1) oraz Konkordatu (art. 1). W konkluzji WSA stwierdził, iż sądy kościelne i świeckie cechują się rozdzielnością jurysdykcji, co oznacza, iż instytucja społeczności wyznaniowej - jak WSA określił sąd kościelny - nie sprawuje wymiaru sprawiedliwości w Rzeczypospolitej Polskiej i nie jest organem władzy sądowniczej. To prowadzi do wniosku, iż L.K. nie może wykazać się interesem

14 Por. Wyrok Wojewódzkiego Sądu Administracyjnego w Warszawie z 27 maja 2013 r. IV SA/Wa 2049/12, LEX nr 1609353. 
prawnym w żądaniu uzyskania danych osobowych opartym na konkretnej powszechnie obowiązującej normie prawnej.

WSA powielił sugestię Ministra, wskazując, iż L.K. może domagać się udostępnienia danych osobowych w oparciu o legitymowanie się interesem faktycznym w otrzymaniu tych danych, ale koniecznym jest uzyskanie zgody na udostępnienie danych osoby, której te dane dotyczą. L.K. zgody tej jednak nie uzyskał. Biorąc to wszystko pod uwagę WSA oddalił skargę.

L.K. wniósł od wyroku skargę kasacyjną, żądając uchylenia zaskarżonego wyroku i rozpoznania skargi albo uchylenia zaskarżonego wyroku i przekazania sprawy do ponownego rozpoznania Wojewódzkiemu Sądowi Administracyjnemu w Warszawie. Oczekiwał również zasądzenia kosztów postępowania, w tym kosztów zastępstwa adwokackiego według norm przepisanych.

Swoją skargę oparł na zarzucie naruszenia dyspozycji art. 44 lit. h ust. 2 pkt 1 - uchylonej już - ustawy z 10 kwietnia 1974 r. o ewidencji ludności i dowodach osobistych. Skarżący podniósł, iż WSA bezpodstawnie przyjął, że nie legitymuje się on interesem prawnym, w związku z czym nie może uzyskać danych adresowych A.K. w trybie przewidzianym w tym przepisie. W odpowiedzi Minister Spraw Wewnętrznych wnosił o jej oddalenie.

\section{Argumentacja Naczelnego Sądu Administracyjnego}

Na wstępie NSA zaznaczył, iż skarga kasacyjna została oparta na usprawiedliwionej podstawie, gdyż zarzut naruszenia art. 44 lit. h ust. 2 - uchylonej już - ustawy z 10 kwietnia 1974 r. o ewidencji ludności i dowodach osobistych jest zasadny.

Następnie NSA w sposób precyzyjny uwypuklił różnice konceptualne w „wąskim” i „szerokim” ujęciu interesu prawnego. W uzasadnieniu zaznaczono, iż interes prawny pojmowany w sposób wąski ma miejsce wówczas, gdy na podstawie obowiązujących przepisów prawa osoba zainteresowana rozstrzygnięciem ubiega się o konkretyzację uprawnienia lub wobec tej osoby organ władzy publicznej podejmuje władczą ingerencję ograniczając uprawnienia lub je cofając, 
jak i nakładając pewien obowiązek. NSA wskazał, iż interes prawny w ujęciu szerokim to możliwość prawna podjęcia obrony na szeroko pojętej drodze prawa - nie tylko w oparciu o prawo polskie i Unii Europejskiej, lecz także przed organami innych państw.

NSA argumentując swoje stanowisko, oparł się przede wszystkim o katalog źródeł powszechnie obowiązującego prawa wymienionego w Konstytucji $\mathrm{RP}^{15}$, wskazując na istniejące $\mathrm{w}$ polskim porządku prawnym ratyfikowane umowy międzynarodowe. W szczególności zwrócił uwagę na Konkordat, który został podpisany 28 lipca 1993 r., a ratyfikowany 28 lutego 1998 r. NSA wprost stwierdził, że skoro umowa międzynarodowa wchodzi w skład polskiego sytemu prawnego, to Konkordat jest jego częścią.

Co więcej, wskazano, iż nie tylko samo podjęcie obrony przed sądem kościelnym w sprawach o stwierdzenie nieważności małżeństwa jest podstawą przyznania interesu prawnego, lecz także „możliwość prawna” zainicjowania takiego postępowania. NSA dodał, iż nie ma wpływu na interes prawny fakt, że w zakresie przedmiotowym przyjęta została kompetencja władzy kościelnej, a nie podmiotu świeckiego.

W dalszej części uzasadnienia odwołano się do orzecznictwa Trybunału Konstytucyjnego ${ }^{16}$. Zaznaczono, iż określona w art. 25 Konstytucji RP zasada ma przymiot zasady ustrojowej, przez co interpretacja wszystkich innych postanowień konstytucyjnych musi być prowadzona w sposób „przyjazny”, a więc zapewniający ich maksymalną możliwość urzeczywistnienia. Dlatego też pominięcie prawa jednostki narusza konstytucyjną zasadę ustrojową, pozbawiając ją prawa do obrony, która może realizować się wyłącznie na drodze przed organami władzy kościelnej, w tym przypadku przed sądem kościelnym.

Konkludując NSA zaznaczył, iż nie ma znaczenia prawnego miejsce podjęcia obrony. To, czy są to świeckie organy wymiaru

\footnotetext{
15 Por. Konstytucja Rzeczypospolitej Polskiej z 2 kwietnia 1997 r., Dz.U. 1997 Nr 78 poz. 483 art. 87 ust. 1 .

16 Por. Wyrok Trybunału Konstytucyjnego z 02 grudnia 2009 r. U 10/07, LEX nr 562823.
} 
sprawiedliwości czy też sądy kościelne, jest prawnie obojętne dla wyprowadzenia interesu prawnego, który w przypadku procesu o stwierdzenie nieważności małżeństwa ma swoje oparcie w ratyfikowanej umowie międzynarodowej.

\section{Ocena wyroku}

NSA uwypuklił kilka zasadniczych kwestii. Po pierwsze trafnie rozróżnił pojęcie interesu prawnego w jego dychotomicznym znaczeniu, wskazując na wąski i szeroki zakres pojęciowy. Dotychczasowe pojmowanie przez organy administracji publicznej interesu prawnego w ujęciu wąskim było nieuprawnione i ograniczało uprawnienia jednostki. Ponadto NSA powiązał interes prawny w ujęciu szerokim z prawem do obrony, gdyż zaznaczył, że prawidłowe rozumienie tego zagadnienia ma miejsce wówczas, gdy osoba zainteresowana posiada możliwość prawną podjęcia obrony na drodze prawa, rozumianej wielopłaszczyznowo, a nie jedynie w oparciu o enumeratywnie wyliczone organy.

Wyrok NSA jest także celnym wskazaniem źródła normy prawnej, w oparciu o którą jednostka może domagać się przyznania interesu prawnego. Pomimo iż proces kościelny regulowany jest normami prawa kanonicznego, to pamiętać należy, iż legitymizacja jego obowiązywania $\mathrm{w}$ polskim porządku prawnym następuje pośrednio w oparciu o katalog źródeł prawa powszechnie obowiązującego w RP. Chociaż art. 87 ust. 1 Konstytucji RP nie mówi o Kodeksie Prawa Kanonicznego czy Instrukcji procesowej Dignitas connubii, to jednak ratyfikowana umowa międzynarodowa jaką jest Konkordat ${ }^{17}$ zapewnia realną możliwość orzekania o ważności sakramentalnego związku małżeńskiego sądom kościelnym, bez jakiejkolwiek ingerencji ze strony władzy świeckiej ${ }^{18}$.

\footnotetext{
17 Por. M. Winiarczyk-Kossakowska, Cz. Janik, P. Borecki (red.), Konkordat polski 1993, Warszawa 2019.

18 Por. Konkordat między Stolicą Apostolską i Rzecząpospolitą Polską, podpisany w Warszawie 28 lipca 1993 r., Dz.U. 1998 Nr 51 poz. 318 art. 10 ust. 3.
} 


\section{Zakończenie}

Glosowany wyrok NSA ma charakter przełomowy. Przede wszystkim wskazano, iż jednostka może domagać się ochrony swoich praw nie tylko przed organami władzy publicznej, lecz także w strukturach kościelnych. Absolutnie niewłaściwym jest stosowanie ograniczeń przy wyprowadzaniu interesu prawnego jedynie w oparciu o normy prawne określające sposób funkcjonowania władzy publicznej w polskim systemie ustrojowym.

Osoba posiadająca możliwość prawną zainicjowania procesu o stwierdzenie nieważności małżeństwa posiada interes prawny przy pozyskiwaniu danych jednostkowych strony przeciwnej, w szczególności w zakresie informacji o adresie i dacie zameldowania ${ }^{19}$ na pobyt stały drugiej strony oraz o adresie i dacie zameldowania na pobyt czasowy wraz z datą upływu deklarowanego terminu pobytu. Tryb i sposób funkcjonowania tej procedury określa Ustawa o ewidencji ludności ${ }^{20}$.

Biorąc powyższe pod uwagę, w szczególności konsekwencje procesowe niedokonania cytacji, nie sposób podzielić poglądu, iż niewskazanie miejsca zamieszkania stałego lub tymczasowego strony pozwanej uniemożliwia normalne prowadzenie sprawy ${ }^{21}$. W praktyce sądowej jest to niemożliwe z uwagi na konieczność procedowania przeciwko jakiejś stronie pozwanej z jednoczesnym zapewnieniem jej prawa do obrony (por. kan. 1620 n. 4 i n. 7 KPK), które objawia

19 Adres zameldowania niejednokrotnie pokrywa się z adresem zamieszkania. W odmiennym przypadku pod adresem zameldowania zazwyczaj kryje się adres domu rodzinnego strony procesowej, co również może gwarantować przekazanie skargi powodowej przez członków rodziny i tym samym czynić zadość wymaganiom procesowym.

20 Por. Ustawa z 24 września 2010 r. o ewidencji ludności, Dz.U. 2010 Nr 217 poz. 1427.

21 Por. H. Stawniak, Komentarz do art. 116 Dignitas connubii, w: T. Rozkrut (red.), Komentarz do Instrukcji procesowej „Dignitas connubii”, Sandomierz 2007, s. 183. 
się koniecznością dostarczenia przez stronę powodową aktualnego adresu zamieszkania byłego współmałżonka.

Dlatego też sądy kościelne w przypadku pozyskania informacji o braku aktualnego adresu zamieszkania strony pozwanej powinny wystawić niezwłocznie stronie powodowej albo występującemu w jej imieniu adwokatowi kościelnemu zaświadczenie potwierdzające niemożliwość dokonania cytacji wskutek nieaktualnego adresu strony przeciwnej, z jednoczesnym zaznaczeniem, iż osoba ta jest stroną powodową toczącego się postępowania o stwierdzenie nieważności małżeństwa. Dzięki temu rozwiązaniu osoba zainteresowana będzie w stanie uprawdopodobnić swoją aktualną sytuację procesową i przedstawić stosowny dokument organowi administracji publicznej.

Konkludując, prawo jako nieodłączny element życia społeczności powinno odpowiadać na jej potrzeby, regulować panujące w społeczności relacje i rozwiązywać pojawiające się w niej problemy ${ }^{22}$. Omówiony powyżej wyrok NSA doskonale wpisuje się w te wymagania.

\section{Legal interest and the ecclesiastical trial. Gloss of approval of the judgement of the Supreme Administrative Court of 8 May 2015, II OSK 2416/13}

\section{Summary}

This gloss concerns the judgment of the Supreme Administrative Court of 8 May 2015, case II OSK 2416/13, in which the court stated that the legal interest conditioning the disclosure of personal data may be enjoyed not only in a trial before a secular court, but also in proceedings before ecclesiastical court.

The gloss layout includes the introduction, the thesis of the order, premises of the factual and legal status, arguments of the Supreme Administrative Court, evaluation of the judgment and the conclusion.

The author fully shares the justification of the judgment. Moreover, he points to the ground-breaking approach to the process of nullity of marriage before the ecclesiastical court, which is the basis for granting a legal interest

22 Por. R. Kamiński, Zakończenie, w: H. Stawniak, R. Kamiński (red.), Chrzest i małżeństwo - harmonizacja ustawodawstwa, Warszawa 2018, s. 193. 
in the procedure of disclosing personal data before a public administration body.

Słowa kluczowe: interes prawny, proces o stwierdzenie nieważności małżeństwa, dane osobowe i ich udostępnianie, miejsce zamieszkania, zameldowanie

Keywords: legal interest, process of nullity of marriage, personal data and their disclosure, place of residence, registration

\section{Nota o autorze}

Dawid Niemczycki - mgr lic. prawa kanonicznego, Iuris Utriusque Magister, prawnik, adwokat kościelny. Doktorant w dyscyplinie nauk prawnych Szkoły Doktorskiej Nauk Społecznych Uniwersytetu Marii Curie-Skłodowskiej w Lublinie. 